\title{
SPECIFIC GRAVITY AND ANTIBACTERIAL ASSAYS OF SOME SYNTHETIC INDUSTRIAL ESSENTIAL OILS
}

\author{
*HATI, S. S. ${ }^{1}$, DIMARI, G. A.. ${ }^{2}$, EGWU, G. O. ${ }^{3}$ \\ \& OGUGBUAJA, V. O. ${ }^{2}$ \\ 1Department of Chemistry, IBB University, Lapai, Nigeria \\ 2Department of Chemistry, University of Maiduguri, Nigeria \\ ${ }^{3}$ Department of Veterinary Medicine, University of Maiduguri, \\ Nigeria \\ *stevehati@yahoo.com
}

\section{ABSTRACT}

Samples of synthetic industrial essential oil (SIEO) were assayed to provide basis for establishing correlation and validation of claims of its density, disinfectant and germicidal properties with its natural counterparts. Specific gravity (SG) and antibacterial assays were carried out on twenty typical SIEO samples that are commonly used in Northern Nigeria. The results show that mean SG was 0.970 with $5 \%$ coefficient of variance (CV) between samples and was not statistically significant following Kolmogorov-Smirnov error protection at 95\% confidence limit. Antimicrobial activity test results consisting of bioautography and minimum inhibitory concentration (MIC) tests present variable effects of the SIEO S. aureus and $E$. coli but are not completely dependent on each other. Generally, the results of SG determinations for SIEO correspond greatly with SG values of most natural essential oils extracts and that up 70\% SIEO showed antibacterial activity. The SIEO studied like their natural counterpart may contain certain antibacterial agents with similar effects to standard Chloramphenicol used in this work. However, further studies are required to justify the safety of the application of SIEO as antimicrobial agents.

Keywords: synthetic fragrance, Staphylococcus aureus, Escherichia coli, human health

\section{INTRODUCTION}

Correlations between the densities of certain pure materials and its constituent have been well reported as a useful tool in assessing the quality of such materials. Pure oils are expected to show this correlation as well (Christian, 2004; Codex, 2005). Similar to other fluids, synthetic industrial essential oils (SIEO) samples show apparent variation in fluidity or observed viscosity. This apparent viscosity is not always proportional to density of the material. However, the constituents of SIEOs contributed by contaminants, however negligible, may affect the correlation to density of individual SIEO sample as with pure oils.

On the other hand, the antibacterial activities of essential oils have been recognized for many years (Hammer et al., 1999); these have lead to the development of synthetic alternatives in the last century (Fortineau, 2004). Previously higher aromatics plants have traditionally been used in folk medicine as well as to extend the shelf life of foods, because they show inhibition against bacteria, fungi and yeasts. This results from secondary metabolism mainly imparted by the chemical properties of essential oils. Extracts from several plant species and essential oils are able to control Gram-negative and Gram-positive bacteria and other microorganisms related to skin, dental caries, and food spoilage (Sartoratto et al., 2004).

A number of research methodologies have been developed within the last decade for the determination of the antibacterial activity testing of essential oils (BSAC, 1997). However, while few investigations have compared large numbers of oils and extracts using methods that are directly comparable amongst essential oils derived from plants (Hood et al., 2003; Bhattacharjee et al., 2005), very little information is available on the antibacterial activities of synthetic essential oils.

In this paper, samples of synthetic industrial essential oil (SIEO) were assayed to provide basis for establishing correlation and validation of claims of its density, disinfectant and germicidal properties with its natural counterparts from specific gravity (SG) and antibacterial assays.

\section{MATERIALS AND METHODS}

Sampling: A total of 100 SIEO samples were collected for this study between 2005 and 2006, from three major points of distributions of SIEO products within Northern Nigeria (Sokoto, Kano and Maiduguri). This followed the detailed survey of the forms of applications of SIEOs in Northern Nigeria as described by Hati et al., (2008). Three major categories of SIEOs applications were identified. These are socio-cultural, fashion and industrial formulations. Due to the wide range of these products, the number of samples collected for this work was obtained from narrowed statistical data of volumes of annual output distribution of the products. This was obtained from manufacturers' distributors in the study area. Thus, only SIEO products with annual output distribution $\geq 4500$ tons/yr were collected for analysis. Twenty (20) typical SIEO products qualified. For each of these, a composite $\left(100 \mathrm{~cm}^{3}\right)$ of five different batches of $20 \mathrm{~cm}^{3}$ each was collected directly from product manufacturers' distributors by decanting into well labeled sterile glass bottles.

Specific Gravity (SG): Specific gravity determinations of SIEO samples were carried out according to method described by ASTM (2006) for liquid fats and oils. This method entails calculating the ratio of the weight of a unit volume of the sample to the weight of a unit volume of water at $25^{\circ} \mathrm{C}$. The ADA-120C (U.K) digital electronic balance was used for the determination in the Advance Research Laboratory of the Department of Chemistry, University of Maiduguri, Nigeria.

Microorganisms and Culture: Antibacterial activity test were carried out against the bacteria Staphylococcus aureus and Escherichia coli. They were obtained from the Department of Veterinary Microbiology and Parasitology, University of Maiduguri. An optimized broth dilution method was employed as described by Hood et al., (2003). The broth cultures were incubated at $35^{\circ} \mathrm{C}$ until it achieved the turbidity of the $0.5 \mathrm{McF}$ arland standard (about 4 hours), confirmed by spectrophotometric reading at $580 \mathrm{~nm}$. In a suspension, cells containing approximately 1 to $2 \times 10^{8} \mathrm{CFU} / \mathrm{ml}$ were obtained for the activity assay.

SIEO Sample Preparation: Twenty (20) experimental SIEO samples were used in this analysis. Stock SIEO samples were prepared using $0.02 \%$ Tween 80 to emulsify $2 \mathrm{~cm}^{3}$ each of the oils to a concentration of $10 \mathrm{~cm}^{3} / \mathrm{dm}^{3}$. Subsequently serial dilutions in the range $2-0.03 \mathrm{mg} / \mathrm{dm}^{3}$ at 0.01 intervals were obtained from this concentration. 
Bioautography Assay: Prior to the minimum inhibitory concentration (MIC) determinations, bioautography assay was carried out for the SIEO samples according to method described by Sawaya et al., (2004) and Mendonça-Filho (2006). Thin layer chromatographic (TLC) plates, composed of Merck Silica gel 60 GF 254, received $5 \mu \mathrm{L}$ of each SIEO sample placed at a distance from $1.5 \mathrm{~cm}$ of the lower edge of the plate. The mobile phase was hexane/ethylacetate / acetic acid (60:40:1, v/v). Bioautography was carried out after airing the TLC plates for over 8 hours. The plates were covered with $20 \mathrm{~cm}^{3}$ of sterile Mueller-Hinton agar at $45^{\circ} \mathrm{C}$ inoculated with the microorganisms and then incubated for 24 hours at $37^{\circ} \mathrm{C}$. After this period each plate was covered with $5 \mathrm{~cm}^{3}$ of a $1 \%$ aqueous solution of 2,3,5 triphenyl tetrazolium chloride and incubated for up to 24 hours at $37^{\circ} \mathrm{C}$. Inhibition zones were visualized and recorded as clear areas against a red coloured background.

Minimum Inhibitory Concentration (MIC) Tests: MIC tests were carried out according to method described by Hood et al., (2003) with modifications by Sartoratto et al., (2004). MIC tests were carried out for samples that showed positive bioautography. Standard Chloramphenicol $\left(0.02\right.$ and $\left.0.04 \mathrm{mg} / \mathrm{dm}^{3}\right)$ was used as reference antibiotic control.
An overnight broth culture was inoculated with the respective microorganisms in serial dilutions in the range $2-0.03 \mathrm{mg} / \mathrm{dm}^{3}$ of SIEO samples. The MIC was read according to procedures described by BSAC (1997), in which MIC is defined as the lowest concentration of analyte (in this case, SIEO) showing inhibition of growth of the organism.

Data Analysis: Results obtained were statistically analysed using coupled Microsoft Excel+Analyse-it $\circledast$ V 2.20 (Analyse-it, 2008). Variations were considered significant at $p \neq 0.05$.

\section{RESULTS}

Results of SG determination and antimicrobial assays are shown on Table 1. The SG of SIEO samples obtained, ranges from 0.834 to 1.057, in which sample SLB1 (0.834) ranked the lowest and sample FKK1 (1.057) marked highest in the range. A normality plot for the SG result is presented in Figure 1. A mean of 0.970 with $5 \%$ coefficient of variance (CV) between specific gravities was obtained for the 20 SIEO samples studied. This CV was not statistically significant following Kolmogorov-Smirnov error protection at $95 \%$ confidence limit.

TABLE 1. RESULTS OF SPECIFIC GRAVITY, BIOAUTOGRAPHY AND MINIMAL INHIBITORY CONCENTRATION (MIC-MG/DM³) OF SIEO SAMPLES

\begin{tabular}{|c|c|c|c|c|c|}
\hline \multirow[t]{2}{*}{ S/No. } & \multirow[t]{2}{*}{ Sample } & \multirow[t]{2}{*}{$\begin{array}{l}\text { Specific } \\
\text { Gravity }\end{array}$} & \multirow{2}{*}{$\begin{array}{c}\text { Bioautography } \\
\text { Test }\end{array}$} & \multicolumn{2}{|c|}{$\begin{array}{c}\text { Micro-organism MIC } \\
\left(\mathrm{mg} / \mathrm{dm}^{3}\right)\end{array}$} \\
\hline & & & & S. aureas & E. coli \\
\hline 1. & ARE2 & 1.021 & + & 0.60 & * \\
\hline 2. & AJO3 & 0.990 & +++ & 0.40 & 1.80 \\
\hline 3. & AYE2 & 0.971 & ++ & 0.08 & 1.70 \\
\hline 4. & AYE3 & 0.980 & ++ & 0.08 & 1.70 \\
\hline 5. & ABA4 & 0.995 & + & 0.40 & 2.00 \\
\hline 6. & ALD5 & 0.957 & - & * & * \\
\hline 7. & ASA6 & 0.975 & +++ & 1.40 & $>2.00$ \\
\hline 8. & ASA7 & 0.960 & +++ & 1.00 & * \\
\hline 9. & ASA8 & 0.956 & + & 1.40 & * \\
\hline 10. & AMA9 & 1.036 & - & 1.00 & * \\
\hline 11. & ANU10 & 0.961 & - & * & * \\
\hline 12. & ADC11 & 0.960 & ++ & 1.50 & $>2.00$ \\
\hline 13. & AMN12 & 0.976 & - & * & * \\
\hline 14. & SSR1 & 0.999 & ++ & 1.00 & 2.00 \\
\hline 15. & FKK1 & 1.057 & - & $>2.00$ & * \\
\hline 16. & FPEP2 & 0.927 & + & 0.60 & 2.00 \\
\hline 17. & SLB1 & 0.834 & +++ & 1.70 & $>2.00$ \\
\hline 18. & SAQ1 & 0.934 & +++ & $0.02^{* \star}$ & 0.07 \\
\hline 19. & TMU1 & 0.960 & + & $>2.00$ & * \\
\hline 20. & TSU2 & 0.950 & ++ & 0.50 & 1.80 \\
\hline 21. & $\begin{array}{c}\text { Control } \\
\text { Antibiotic } \\
\text { (Chloramph- } \\
\text { enicol) }\end{array}$ & & & 0.02 & 0.04 \\
\hline
\end{tabular}

Bioautography Test : +One active fraction; ++ two active fractions; +++ three active fractions

Antimicrobial activity test results consisting of bioautography and MIC (Table 1) present variable effects of the SIEOs on the microorganisms (S. aureus and E. coli) but are not completely dependent on each other. As some samples indicated similar active compound (one or more inhibition zones), but with different MIC values. For a better appreciation of these, further analyses of the results are graphically presented in Figure 2 and 3 on a percentage basis.
The MIC results (Figure 2) are presented according to literature (Duarte et al. 2004) in which strong, moderate and weak activities $\left(0.05-0.5 \mathrm{mg} / \mathrm{dm}^{3}, 0.06-1.5 \mathrm{mg} / \mathrm{dm}^{3}{ }^{3}\right.$ above $1.5 \mathrm{mg} / \mathrm{ml}$ respectively are shown. Analyses of the results of MIC present a general observation of 7,8 , and 13 as strong $\left(0.05-0.5 \mathrm{mg} / \mathrm{dm}^{3}\right)$, moderate $\left(0.06-1.5 \mathrm{mg} / \mathrm{dm}^{3}\right.$ ) and weak (above $1.5 \mathrm{mg} / \mathrm{dm}^{3}$ ) activity respectively from all SIEO samples on the microorganisms. There were 12 observations for inactive effects. Individually however, out 
of the 20 SIEO samples, only one-sample presented strong activity on both microorganisms, while two and three samples showed weak and inactive effects respectively on both microorganisms. These show that an overall $70 \%$ of SIEO samples were active on the microorganisms, while $30 \%$ were inactive.

Due to their natural characteristics, it was observed that $S$. aureus presented more susceptibility than $E$. coli to the SIEO samples. Figure 3 shows this comparison, in which $S$. aureus showed 25\%, $40 \%$ and $50 \%$ susceptibility at the three activity concentration ranges for strong, moderate and weak activities respectively.

As a result, $85 \%$ overall susceptibility was observed, with only $15 \%$ non-susceptibility effect. While for $E$. coli there were $5 \%, 0 \%$ and $50 \%$ susceptibility at strong, moderate and weak activity concentration ranges respectively. Thus an overall susceptibility effect of $55 \%$ and up to $45 \%$ non susceptibility effects was observed for $E$. coli.

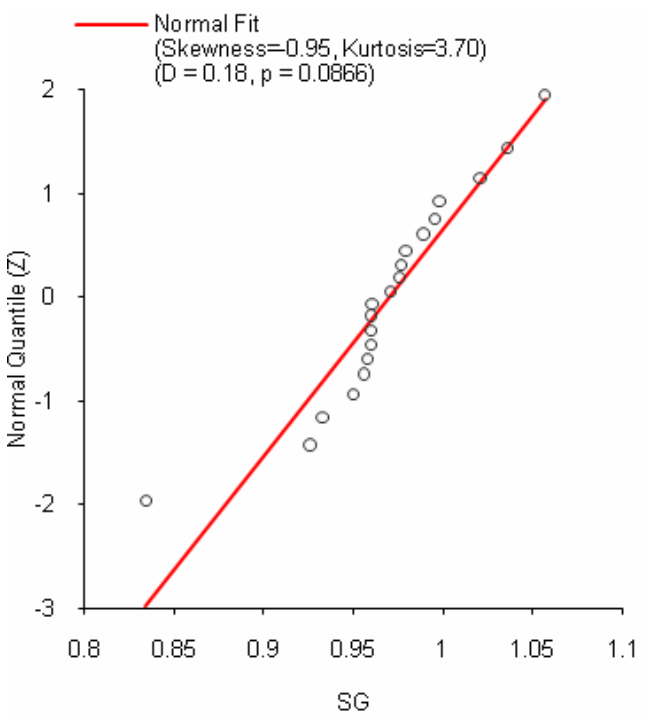

FIG. 1. NORMALITY PLOT OF SGS OF SIEO

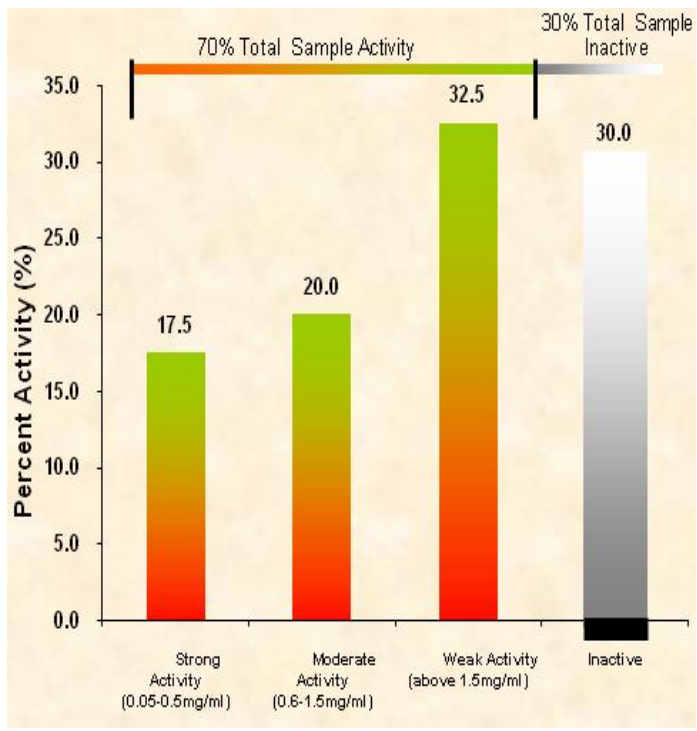

FIG. 2. OVERALL MINIMAL INHIBITORY CONCENTRATION (MIC-mg/ML) OF SIEO SAMPLES EXPRESSED IN PRECENTAGE ECTIVITY

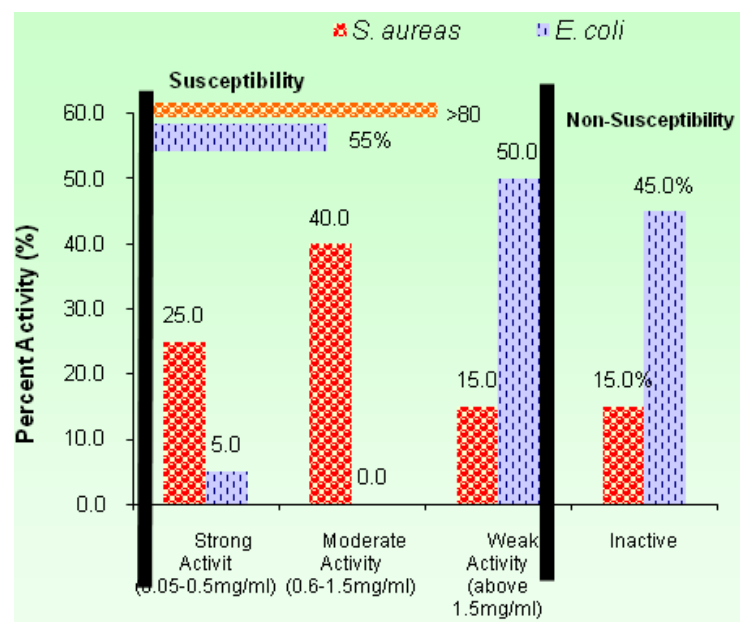

\section{FIG. 3. PERCENTAGE SUSCEPTIBILITY VARIATION OF S. aureus AND E. coli TO MINIMAL INHIBITORY CONCENTRATION (MIC-mg/ml) OF SIEO SAMPLES AT VARIOUS LEVELS OF ACTIVITY}

\section{DISCUSSION}

The result of SG determinations confirms that the apparent viscosity of oil sample do not correspond with their density or specific gravity. Samples SLB1 (0.834) and FKK1 (1.057) showed the lowest and highest SG respectively, and are apparently of the same viscosity. On the other hand, sample FKK1 with the highest SG (1.057) is apparently less viscous than other samples such as SSR1 and ASA6 with SG of 0.999 and 0.975 respectively.

However samples SLB1 and FKK1 are samples of products with slightly diverse applications in Northern Nigeria. Unlike FKK1, SLB1 is applied as industrial fragrance additive in the production of soaps especially. Though they both serve as fuel in burning fragrance materials in Northern Nigeria, FKK1 is used mostly as enhancer in the blending combinations of SIEO.

Generally, the results of SG determinations for SIEOs correspond greatly with the values for the SG of most natural essential oils extracts (Coleman, 2003).

The fact that up to $70 \%$ SIEO showed antibacterial activity allows the conclusion that most SIEO like their natural counterpart do contain certain antibacterial compounds with similar effects to standard Chloramphenicol used in this work. It was also observed that there were similarities in the MIC of SIEO samples with natural oils from plant extracts (Mathew et al., 2006; Duarte et al., 2004; Johannes et al., 2001). Therefore, SG result shows that apparent viscosity and SG of SIEO do not correlate. They however show good similarities in their ranges with other liquids and oils e.g. edible oils (Simetric, 2006).

One general, but significant reason for the high percentage inhibitory effects of SIEO on the bacterial activity is the hydrophobicity of SIEO and their constituent, which enables them to partition the lipids of the bacterial cell membrane and mitochondria, disturbing the cell structure and rendering them more permeable. This led to leakage and consequently exits of critical components of the cell that leads to death (Sikkema et al., 1994; Denyer \& Hugo, 1991). Another factor may be due to the large group of aldehydic components, usually as fragrant materials (RUK, 2004) of essential oils, such as cinnamaldehyde which are antioxidants, capable of inhibiting bacterial growth (Prabuseenivasan et al., 2006). 
However, according to NERL (2006), certain contaminants or additives may have conferred these effects rather than the fragrant compounds present. Such contaminants or additives range from high levels of residual metal catalyst from chemical reactions in the manufacturing processes (e.g. Nickel) and Polynuclear aromatic hydrocarbons (e.g. naphthalene and benzo (a) pyrene) sourced from raw materials such as petroleum products. Since these are found in higher quantities in SIEO than in plant extracts. This may be corroborated by the UNEP (2002) report, that for instance, in Daphnia pulex, $\mathrm{LC}_{50}$ for naphthalene is $1.0 \mathrm{mg} / \mathrm{L}$, for phenanthrene $0.1 \mathrm{mg} / \mathrm{L}$ and for benzo(a)pyrene is $0.005 \mathrm{mg} / \mathrm{L}$. These substances are equally higher in the SIEO studied and may have conferred the observed effects on the microorganisms studied in this work.

Contrary to the observations by Zaika (1988), in which gram positive bacteria were more resistant to essential oils of natural origin. In this work, the gram negative $E$. coli showed more resistance. Though the choice of Chloramphenicol as standard reference in this work was advised by its use to combat serious infections for which other antibiotics are either ineffective or contraindicated, its broad spectrum (Burnham et al., 2000) and, in conformity with recent literatures (Hood et al., 2003; Sartoratto et al., 2004; Duarte et al., 2004) on similar studies. However, sample ASAQ, a fashion trend product gave similar MIC value as Chloramphenicol, indicating that there may be more SIEOs as potent.

\section{CONCLUSION}

The SG of SIEO did not show correlation with concentration levels of toxicant studied, showing no evidence of dependency. The result of antibacterial assay (minimum inhibitory concentrations), though validates to some extent, the claim of efficacy of SIEO as germicidal and disinfectant agent by up to $70 \%$, general activity of SIEO on S. aureas and $E$. coli, is yet unclear whether this effects were conferred by fragrant compounds, toxicants or other active components. But results of this study show good corroboration with reports of antibacterial assay results obtained for natural essential oil extracts. Further studies are required to justify the safety of the application of SIEO as antimicrobial agents.

\section{ACKNOWLEDGEMENT}

The authors acknowledge the support of Sauki Biomedics Laboratories Maiduguri and Department of Veterinary Microbiology and Parasitology, University of Maiduguri for the antibacterial activity tests.

\section{REFERENCES}

Analyse-it $\circledast$ (2008) General and Clinical Laboratory Analyses Software Version 2.20 Analyse-it Software Ltd. PO Box 77, Leeds, LS12 5XA, England

ASTM: American Society for Testing and Materials (2006) Standard Test Method for Specific Gravity of Oils and Liquid Fats. Book of Standards. Volume 15.04 D5355-95. ASTM International, PA 194282959 USA

Bhattacharjee, I.; Ghosh, A. \& Chandra G. (2005) Antimicrobial Activity of Essential Oil of Cestrum diurnum( $L$ ) (Solanales: Solanaceae). African Journal of Biotechnology, 4 (4): 371-374

Burnham, T. H.; Snitker, J. A. \& Kastrup, E. K. (2000). Facts and Comparisons. Drug Facts and Comparisons, (eds). St. Louis, MO

BSAC: British Society for Antimicrobial Chemotherapy. (1997). A Guide to Sensitivity Testing: Report of working party on antibiotic sensitivity testing of the British Society for Antimicrobial Chemotherapy. Journal of Antimicrobial Chemotherapy, 1991; 27: Supplement D:1-50.
Christian, G. D. (2004). Analytical Chemistry. $6^{\text {th }}$ Ed. John Wiley \& Sons. USA

Codex, A. (2005). "Named Vegetable Oils". CODEX STAN. 210(8):11-21.

Colman, D. (2003). Herbal Luxuries. http://www.deancolman.com (date accessed, 28 July, 2006)

Denyer, S. P. \& Hugo, W. B. (1991) Biocide-induced damage to the bacterial cytoplasmic membrane In: Mechanisms of Action of Chemical Biocides. Denyer S. P\& Hugo, W. B. (eds). The Society for Applied Bacteriology, Technical Series No 27. Oxford Blackwell Scientific Publication, Oxford.

Duarte, M. C. T.; Sartoratto, A.; Machado, A. L. M.; Delarmelina, C.; Figueira, G. M. \& Rehder, V. L. G. (2004) Composition and antimicrobial activity of essential oils from Aromatic Plants Used in Brazil. Brazilian Journal of Microbiology 35:275-280

Fortineau, A. (2004) Chemistry Perfumes Your Daily Life. Journal of Chemical Education, 81(1): 45-50.

Hati, S. S.; Dimari, G. A.; Abdulrahman F. I.; Egwu, G. O. \& Ogugbuaja, V. O. (2008). Dioxin Contaminations of Synthetic Industrial Essential Oils (Turare) Utilized in Northern Nigeria. European Journal of Scientific Research, (21)1: 145-153

Hood, J. R.; Wilkinson, J. M. \& Cavanagh, H. M. A. (2003). Evaluation of common antibacterial screening methods utilized in essential oil research. Journal of Essential Oil Research, 1(3): 412

Hammer, K. A.; Carson, C. F. \& Riley, T. V. (1999). Antimicrobial activity of essential oils and other plant extracts. Applied Microbiology, 86 (6): 985

Johannes, N. ; Zitterl-Eglseer, K.; Deans, S. G. \& Franz, C. M. (2001). Essential oils of different cultivars of Cannabis sativa $L$. and their antimicrobial activity. Flavour and Fragrance Journal, (16) 4: $259-262$

Mathew, J.; Sabulal, B.; George, V.; Dan, M. \& Shiburaj, S. (2006). Chemical Composition and Antimicrobial Activity of the Leaf Oil of Amomum cannicarpum (Wight) Bentham ex Baker. Journal of Essential Oil Research, 12-17.

Mendonça-Filho, R. R. (2006) Modern Phytomedicine. Turning Medicinal Plants into Drugs Edited by I. Ahmad, F. Aqil, and M. Owais WILEY-VCH Verlag GmbH \& Co. KGaA, Weinheim ISBN: 3-527-31530-6.

NERL: National Exposure Research Laboratory (2006). 2006Common synthetic fragrances found to harm wildlife, humans. http://www.epa.gov/nerlesd1.com (date accessed, 8 August, 2006).

Prabuseenivasan, S.; Jayakumar, M. \& Ignacimuthu, S. (2006). In vitro antibacterial activity of some essential oils. Complimentary and Alternative Medicine, 6: 39-44.

RUK: Robertet United Kingdom (2004). General Notes on Perfumery and Training Kit. - Handbook. RUK- Surrey GU272QU, England- 1010651. 
Sartoratto, A.; Machado, A. L. M.; Delarmelina, C.; Figueira, G. M.; Duarte, M. C. T. \& Rehder, V. G. (2004). Composition and antimicrobial activity of essential oils from aromatic Plants used in Brazil. Brazilian Journal of Microbiology, 35:275-280.

Sawaya, A. C.; Kirllian, H. F.; Souza, S.; Maria, C.; Ildenize, M.; Cunha, B. S. \& Shimizu, M. T. (2004). Analysis of the composition of Brazilian propolis extracts by Chromatography and evaluation of their in vitro activity against Gram-positive bacteria. Brazilian Journal of Microbiology, 35:104-109.

Sikkema, J.; De Bont, J. A. M. \& Poolman, B. (1994). Interactions of cyclic hydrocarbons with biological membranes. Journal of Biology and Chemistry, 269:8022-8028.
Simetric, (2006). Mass, Weight, Density and Specific Gravities of Liquids. http://www.simetric.co.uk (Accessed Date: February 20, 2007).

UNEP: United Nation Environmental Programme (2002). Regionally Based Assessment of Persistent Toxic Chemicals. Sub-Saharan Report. GEF, Switzerland. UNEP Chemicals 11-13

Zaika, L. L. (1988). Spices and herbs: their antibacterial activity and its determination. Journal of Applied Bacteriology, 82: 759762 